\title{
Contributions regarding combating obesity in middle school students (girls) from rural areas through motor activities
}

\author{
Adrian COJOCARIU1, Valentin ALBU²
}

\begin{abstract}
The present research aims to identify and justify adequate forms to practice physical exercises, curricular and extracurricular, that lead to effective results in combating obesity in middle school students. The study group consisted of 12 female subjects, pupils of middle school age from rural areas. The experiment was conducted during seven months, including an initial test in October and a final one in May. The final results show a clear improvement in the value of the body mass index (BMI) of subjects involved in the experiment. Therefore, it is proposed to use the physical program from the experiment in order to decrease weight, in overweight or obese pupils in middle schools.
\end{abstract}

Key words: body mass index, overweighting, weight, pupils.

\section{Rezumat}

Cercetarea de față urmărește să identifice și să justifice unele forme adecvate de practicare a activităților motrice, curriculare și extracurriculare, care să conducă la rezultate eficiente în combaterea obezității la elevii din ciclul gimnazial. Grupul de studiu a fost format din 12 subiecți (fete), eleve de vârstă școlară gimnazială, din mediul rural. Experimentul a fost efectuat pe parcursul a șapte luni, incluzând o testare inițială, în luna octombrie, respectiv una finală, în luna mai. Rezultatele finale atestă o îmbunătățire evidentă a valorii indicelui de masă corporală (IMC) a subiecților din cadrul experimentului. Ca urmare, se propune utilizarea sistemului de mijloace din cadrul experimentului în vederea scăderii în greutate, la elevii supraponderali sau obezi din ciclul gimnazial.

Cuvinte cheie: indice de masă corporală, supraponderalitate, greutate, elevi.

\footnotetext{
${ }^{1}$ Assoc. Prof., „Alexandru Ioan Cuza” University of Iași, Romania, Faculty of Physical Education and Sports, Interdisciplinary Research Centre in Human Movement Science, e-mail: cadriano@uaic.ro

2 Teacher, Technological High School Bucecea, Botoșani County, Romania
} 


\section{Introduction}

Obesity is currently the most frequent health issue among children; in 2015, it affected over 100 million children worldwide [1]. Furthermore, the data of the World Health Organization stand to show that it occurs more frequently in females than in males [2]. In addition, the interest currently granted to the epidemiology of obesity derives from the fact that the number of deaths due to the consequences of this disease increases significantly every year, not only among adults, but also among children, all over the world, regardless of the geographic area or of the economic level.

Weight issues in children and adolescents have become ever more frequent in Romania and elsewhere, and the reasons are most often related, it seems, to wrong decisions concerning lifestyle. Obesity in these categories of population appears only in exceptional cases as a symptom of a primary condition. For therapeutic success, an essential previous condition is the intention of the family and of the teenager to change their lifestyle, which is far from an easy task. From a motivational perspective, cultivating the feeling of dissatisfaction for one's own body image, with the help of parents, friends, etc. may stimulate the wish to lose weight $[3,4]$. In the same direction, it is worth mentioning the manifestation of a positive influence by the media, by promoting beauty standards constantly, thus favouring a comparison between them and one's own body.

Though it may seem simple at first glance, the effective treatment for obesity is a desideratum that is hard to obtain in clinical practice. Dietary treatment is considered fundamental in case of obesity and it consists in low-calorie portions, but that should not cause a nutritional misbalance, insofar as it is possible [5].

On the other hand, however, obesity among children and adolescents may be reduced or combated also using means available to us, namely to specialists in physical education and sport.

In this direction, the synthesis of specialized studies attests positive effects of practicing sports activities among children and adolescents, especially sports games [6].

It has also been concluded that the effects of practicing physical activities on reducing obesity are more obvious when they are applied on a long- term basis (over 18 months) and when they are associated with a proper diet [7].

As a response to this current situation, both the USA [8] and the EU [9] have implemented adequate strategies to prevent and reduce obesity, which include curricular and extracurricular physical activities among children and adolescents. Concerning Romania, we have identified elements that prefigure an intervention regarding the obesity phenomenon within the National Strategy for Sport 2016-2032 [10].

\section{Purpose and hypothesis}

In agreement with these realities, the current research aims to identify and justify certain proper forms of practicing motor activities, both curricular and extracurricular, which can lead to effective outcomes in the fight against obesity, conducted among rural female middle school students. We have started from the hypothesis that the system of influences used for the study group (the independent variable) will contribute effectively to weight loss and to a reduction of overweight and obesity, implicitly, thus improving the subjects' quality of life.

\section{Material and method}

The experimental research was conducted throughout around seven months, in the period October - May, during the school year. After measuring the body mass index of children at Middle School no. 1 in Vlădeni, Botoțani County, (which represented the initial testing) we have begun the selection of subjects for our research. Throughout the experiment, these female students practiced physical activities both during physical education classes and on an extracurricular basis, following the schedule presented below:

- physical education classes: $5^{\text {th }}, 6^{\text {th }}, 7^{\text {th }}$ form - two hours a week; $8^{\text {th }}$ form -one hour a week.

- extracurricular activities: Monday and Thursday 17:00-18:00 aerobic gymnastics;

The initial and the final testing were conducted in the month of October and May, respectively. We have measured body weight and height and then we have calculated the body mass index (BMI). We have prepared and then measured the female students in the school gymnasium. 
Therefore, the study group comprised 12 subjects (girls), middle school female students aged between 11 and 14, from the rural environment (commune of Vlădeni, Botoșani County, Romania), who featured obesity, through high values of body mass index (Table 1). We have discussed beforehand with the parents or tutors of these female students, who gave their consent for this experiment, and then we received the medical consent.

We mention that BMI assessment among children and adolescents, besides body weight and height, must also take into account and average data of children of the same age and gender. (Table 1)

Table no. 1 - Comparative values of BMI among research subjects (initial testing) and worldwide (11), concerning overweight and obesity among girls aged between 11 and 14

\begin{tabular}{|c|c|c|c|c|c|}
\hline \multirow[t]{2}{*}{ No. } & \multirow[t]{2}{*}{ Initials } & \multirow[t]{2}{*}{ Age } & \multirow{2}{*}{$\begin{array}{c}\text { BMI } \\
\text { Initial } \\
\text { testing }\end{array}$} & \multicolumn{2}{|c|}{$\begin{array}{c}\text { BMI } \\
\text { WHO reference } \\
\text { values }\end{array}$} \\
\hline & & & & Overweight & Obesity \\
\hline 1. & C.L. & 11 & 25.75 & $>19.8$ & $>23.7$ \\
\hline 2. & J.I. & 12 & 32.39 & \multirow{5}{*}{$>20.8$} & \multirow{5}{*}{$>25$} \\
\hline 3. & M. A. & 12 & 27.53 & & \\
\hline 4. & U.P. & 12 & 29.21 & & \\
\hline 5. & H.R. & 12 & 28.98 & & \\
\hline 6. & C.T. & 12 & 28.37 & & \\
\hline 7. & V.I. & 13 & 29.03 & $>21.8$ & $>26.2$ \\
\hline 8. & R.G. & 14 & 27.69 & \multirow{5}{*}{$>22.7$} & \multirow{5}{*}{$>27.3$} \\
\hline 9. & U.G. & 14 & 28.82 & & \\
\hline 10. & B.J. & 14 & 35.27 & & \\
\hline 11. & B.D. & 14 & 32.27 & & \\
\hline 12. & B.L. & 14 & 26.93 & & \\
\hline
\end{tabular}

Hence, we conclude that research subjects, with one exception, range in the category of obesity, through high values of the BMI.

Presentation of the independent variable In order to obtain positive results, we have requested the assistance of parents, for both motivational support and the modifications of children's nutritional regime. Hence, we have asked them to write down the foods bought and cooked, which represented the basis of necessary discussions and corrections. In addition, we have also discussed with the parents, in order to explain the risks and complications of obesity and in order to persuade them of the need for this experimental program. We have assessed the nutritional habits, the life regimen, and then we discussed with the parents and legal tutors of these children. The result was surprising. Many of these parents are abroad for work and children are left in the care of grandparents. A girl is raised by the father, the mother being deceased; one child was abused by the stepfather; the grandparents of these children guide themselves by the old principle "fat and beautiful," but not healthy. The involvement of parents in this experiment has been an essential element and we managed to implement it after many discussions. After persuading them of the risk of seeing their children and grandchildren suffering from serious health conditions in the future, and of the effect upon the children's psyche, all due to this disease, we stimulated them to become involved in this project.

Throughout the intervention (7 months), within the physical education classes we have used the differentiated treatment of these female students, by focusing on exercises for strengthening muscles and the osteoligamentary system, on improving suppleness and the indices of motor skills. We have also focused on longer-term efforts, meant to stimulate aerobic metabolism and to contribute to the increase of fitness level (e.g., runs on various distances, sports games, etc).

Concerning the aerobic gymnastics classes, with the duration of one hour, they were conducted two times a week, favouring the implication of the main body functions and the manifestation of endurance motor skills. We have used certain specific simpler or more complex exercises (stretching exercises, dance elements, analytical exercises on segments, muscle groups and areas, structures of combined exercises, etc). Classes were oriented towards the following finalities:

-The development of aerobic effort capacity;

-The development of muscle force and tone;

-The development of joint mobility and muscle elasticity;

-The improvement of neuromuscular coordination. 


\section{Findings and discussions}

The findings obtained at the initial and the final testing, within the research, are featured in the Table below (Table 2).

Table no. 2 BMI values among research subjects, at the two tests

\begin{tabular}{|c|c|c|c|c|}
\hline No. & Initials & $\begin{array}{c}\text { Initial } \\
\text { testing }\end{array}$ & $\begin{array}{c}\text { Final } \\
\text { testing }\end{array}$ & Progress \\
\hline 1. & C.L. & 25.75 & 23.73 & 2.02 \\
\hline 2. & J.I. & 32.39 & 29.38 & 3.01 \\
\hline 3. & M. A. & 27.53 & 25.06 & 2.47 \\
\hline 4. & U.P. & 29.21 & 27.18 & 2.03 \\
\hline 5. & H.R. & 28.98 & 27.09 & 1.89 \\
\hline 6. & C.T. & 28.37 & 26.98 & 1.39 \\
\hline 7. & V.I. & 29.03 & 26.49 & 2.54 \\
\hline 8. & R.G. & 27.69 & 26.13 & 1.56 \\
\hline 9. & U.G. & 28.82 & 27.33 & 1.49 \\
\hline 10. & B.J. & 35.27 & 32.81 & 2.46 \\
\hline 11. & B.D. & 32.27 & 27.88 & 4.39 \\
\hline 12. & B.L. & 26.93 & 24.99 & 1.94 \\
\hline
\end{tabular}

Because the values of reference are differentiated by age (Table 1), we believed it necessary to conduct a succinct analysis of individual values obtained for our students. Hence, for the female student aged 11, the final value drops to the limit of obesity. Concerning the girls aged 12 and 13, despite the improvements, BMI values are still over the obesity limit. Among female students aged 14, we have also noted sometimes important decreases in values, two of them dropping to the overweight range, while one of them to the obesity threshold.

After conducting the experiment and the two measurements (initial and final) of the BMI, findings were processed statistically, using MS Excel and SPSS 20 for Windows (Paired Sample Test) (Table $3)$.
Table no. 3 - Statistical processing of BMI values among research subjects, at the two tests

\begin{tabular}{|l|c|c|c|}
\hline \multicolumn{1}{|c|}{ Statistical indicator } & $\begin{array}{c}\text { Initial } \\
\text { testing }\end{array}$ & $\begin{array}{c}\text { Final } \\
\text { testing }\end{array}$ & Progress \\
\hline Arithmetic mean & $\mathbf{2 9 . 3 5}$ & $\mathbf{2 7 . 0 9 *}$ & $\mathbf{2 . 2 7}$ \\
\hline Minimum value & 25.75 & 23.73 & 1.39 \\
\hline Maximum value & 35.27 & 32.81 & 4.39 \\
\hline Standard deviation & 2.68 & 2.33 & 0.82 \\
\hline Variability coefficient & $9.14 \%$ & $8.61 \%$ & 0.53 \\
\hline
\end{tabular}

Legend: * - highly significant difference compared to initial testing $(\mathrm{p}=0.000)$

We have found an important improvement of BMI values, with significantly lower values at the final testing $(p=0.000)$, even though, as we have mentioned above, modifications are not spectacular. We also highlight a good homogeneity of values, with an increasing trend from one test to another.

From this perspective, the findings obtained confirm those of similar studies [6] concerning the beneficial but not extremely important short-term influence of motor activities upon this category of subjects.

Furthermore, these findings are consistent with previous ones [7], which underscore the need to continue practicing physical activities on a longterm basis and in addition to a proper diet.

We must also note, however, certain limits of the current study, among which the relatively small number of subjects, the short duration of the research, as well as the limited capacity of monitoring the diet of subjects.

\section{Conclusions}

The findings obtained in the present research largely confirm the hypothesis formulated at the beginning, thus highlighting the beneficial influence of the system of curricular and extracurricular activities conducted by the research subjects on weight loss and BMI reduction, implicitly.

The important and highly significant differences recorded between the two tests, while not attesting a fight against obesity, still suggest a positive trend, which should be maintained and supported by a proper meal portioning, which may have far more obvious results on a long-term basis. 
Thus, our findings justify the use of the system of means within the experiment in order to achieve weight loss among overweight or obese middle school students.

In addition, this study provides the perspective of a compared research regarding the efficiency of using other forms of motor activity for reducing and combating obesity, especially among children and adolescents from the rural environment.

On the other hand, our findings justify the intensification of endeavours meant to implement the measures stated in national and EU strategies concerning the use of physical and sporting activities for preventing and combating obesity.

\section{References}

1. The GBD 2015 Obesity Collaborators. (2017). Health Effects of Overweight and Obesity in 195 Countries over 25 Years. New England Journal of Medicine. DOI:10.1056/NEJMoa1614362.

2. http://www.who.int/mediacentre/factsheets/fs311/en/ (accesed at 10.09.2017).

3. Stormer S.M., Thompson J.K. (1996). Explanations of body image disturbance: a test of maturational status, negative verbal commentary, social comparison, and sociocultural hypotheses, Int J Eat Disord., 19(2), 193-202.

4. McCabe M.P., Ricciardelli L.A. (2001). The structure of the perceived sociocultural influences on body image and body change questionnaire, International Journal of Behavioral Medicine, 8(1), 19-41.

5. Mincu I., Segal B. (1989). Orientări actuale în nutriţie, Editura Medicală, București, 56.

6. Kim K., Ok G., Jeon S., Kang M., Lee S. (2017). Sport-based physical activity intervention on body weight in children and adolescents: a meta-analysis, Journal of Sports Sciences, 35(4), 369-376.

7. Jakicic J.M., Rickman A.D., Lang W., Davis K.K., Gibbs B.B., Neiberg R., Marcus M.D. (2015). Time-based physical activity interventions for weight loss: A randomized trial, Medicine and Science in Sports and Exercise, 47(5), 1061-1069.

8. Khan L.K., Sobush K., Keener D., Goodman K., Lowry A., Kakietek J. et al. (2009). Recommended community strategies and measurements to prevent obesity in the United States, MMWR Recomm Rep, 58(RR-7), 1-26.

9.https://ec.europa.eu/health/sites/health/files/nutrition physi cal activity/docs/childhoodobesity actionplan 20142020 en.pd $\underline{\mathrm{f}}$ (accesed at 15.09.2017).

10.http://mts.ro/wp-content/uploads/2016/02/Strategianationala-pentru-SPORT-v2016-v2.pdf (accesed at 15.09.2017). 11.http://www.who.int/growthref/bmifa girls 5 19years per.p df?ua $=1$ (accesed at 10.09.2017). 